\title{
Centenary of the University of Brussels
}

$\mathrm{T}$ HE Université Libre de Bruxelles was founded on November 20, 1834, by Theodore Verhaegen (1796-1892) and a group of friends, a few days after the opening on November 4 of the Catholic University at Louvain. It was housed at first in the buildings now occupied by the Musée Moderne, but was removed in 1842 to the site in the rue des Sols which it occupied until recently. After the War, mainly through the generosity of the "Commission for Relief in Belgium" and the Rockefeller Foundation, a new Cité Universitaire was created at Solbosch, adjoining the Bois de la Cambre. These buildings include a very fine hall and library with appropriate buildings for the faculties of arts and law, whilst the faculties of science are housed in a capacious but more utilitarian building behind the main frontage. A large hostel has also been provided for men and women students, with generous accommodation for non-residents.

The centenary celebrations extended over three days, November 18-20. On the evening of November 18, a reception was given by the Collège des bourg. mestres et échevins at the Hotel de Ville, where the guests were received by Bourgmestre Max. The principal function took place in the hall of the University in the presence of H.M. the King of the Belgians. This session was presided over by Bourgmestre Max, and addressed by M. Paul Hymans (Foreign Minister), M. Maistriau (the retiring Minister of Public Instruction), and representatives of past and present students. The Rector, M. Bogaert, announced the names of some twenty-five new doctors honoris causa, of whom the first was the
King himself. In addition to those associated with the faculties of philosophy and of law, the faculty of medicine had nominated Sir Henry Dale, director of the National Institute for Medical Research in Great Britain, Prof. van den Bergh of the University of Utrecht, and Sir Frederick Gowland Hopkins, president of the Royal Society. The faculty of pure science had nominated Profs. Cayeux, Cotton and Hadamard, members of the Institut de France, Prof. Krismer, emeritus Professor of the École Militaire at Brussels, and Prof. T. M. Lowry of the University of Cambridge. The faculty of applied science had nominated M. Pelseneer, permanent secretary of the Académie Royale de Belgique, Prof. Swarts of the University of Ghent, Prof. Debye of the University of Leipzig (at present visiting professor at Liège on the Francqui Foundation) and Prof. Janet, honorary professor of the University of Paris. At the conclusion of the ceremony, the past and present honorary doctors were received by the King in person.

Public lectures on legal and philosophical subjects were given in the afternoon, and in the evening of November 19 the guests were entertained at dinner by $\mathbf{M}$. Hymans at the Fondation Universitaire. The celebrations were continued on Tuesday, November 20 , and concluded with a banquet in the University hall, which was attended by 826 guests.

The celebrations were marked by much enthusiasm and were of an extremely hospitable character. There can be no doubt that in its new quarters the University has every prospect of a brilliant and successful future.

\section{Archæological Excavations in Shetland}

$\mathrm{M}^{\mathrm{s}}$ R. A. O. CURLE gave an interesting account to Section H (Anthropology) at the Aberdeen meeting of the British Association on the excavation conducted by him during the past four years in Shetland. A low promontory projecting into the Voe which lies sheltered behind the lofty promontory of Sumburgh Head, the most southerly point of Shetland, bears on its crest the ruin of a late sixteenth century dwelling house, to which Sir Walter Scott in "The Pirate" gave the name of "Jarlshof". Beneath and all around this ruin lie numerous remains of ancient dwellings, ranging from before the Bronze Age reached Shetland in the latest phase of that culture, through the period of the brochs and their secondary buildings, to the coming of the Norsemen in the ninth or tenth century and even later, for relics found in the vicinity of foundations exposed last summer indicated for them a fifteenth or sixteenth century date.

A storm some thirty years ago exposed a range of buildings on the sea front, which were at that date excavated by the proprietor. These consisted of the remains of a broch and a series of later buildings extending probably well into the Christian era. The Office of Works, having accepted guardianship of these remains, resolved to explore the ground in the immediate vicinity, and invited Mr. Curle to direct the operations on its behalf. The work has now been in progress for a short period each year since 1931 . A group of prehistoric dwellings five in number. all lying practically contiguous to one another, have been explored and apparently exhausted. A dwelling, excavated during the past summer, was found to consist of an open court some $20 \mathrm{ft}$. long and $10 \mathrm{ft}$. broad, rounded at the inner end, with lateral chambers on the sides. The paving suggested the presence of cattle inside the house, a practice followed in much later days. This was confirmed by the discovery of a whale's vertebra, fixed into a wall to furnish a loop for a tether. This dwelling had been partially broken down and then extended by further constructions in front of the original entrance. From this later building a drain had been carried towards lower ground to the south-east. Evidence of a still later period was the closing of that drain by a stairway leading to another dwelling. This second dwelling was obviously of much later construction than the first. In its turn it had had three periods of occupancy, the earliest of which was seemingly contemporary with the latest occupation of the first house. The third occupation of the second house was remarkable for evidence of the advent of artificers in bronze, who cast swords and axes in clay moulds. These dwellers closed the original entrance, which lay at the foot of the stair above referred to, and opened a new entrance at the opposite end of the house. The bronze workers used clay moulds, and, to release their castings, broke the moulds and threw the fragments over the closed entrance and into disused chambers beyond, where they lay, not on the floor level, but in the 